\title{
Blood products: when to use them and how to avoid them
}

Jean-François Hardy MD FRCPC,

Sylvain Belisle MD FRCPC,

Danielle Robitaille MD FRCPC
"Blood transfusion is like marriage: it should not be entered upon lightly, unadvisedly or wantonly, or more often than is absolutely necessary"

$$
\text { R.W. Beal' }
$$

Before the advent of the acquired immune deficiency syndrome (AIDS), blood transfusion was felt to be an almost benign process and the use of blood products increased steadily, to the point where blood component preparation could barely keep pace with increasing demand for blood products. Then, AIDS modified the perception of the safety of blood dramatically, both for physicians and patients, resulting in major changes in the use of blood products between 1980 and 1985 . $^{2}$ The extent of this concern with the complications secondary to the transfusion of blood products is well illustrated by the number of texts published on the subject in recent years. ${ }^{3-6}$

The objectives of this refresher course are to (1) Review briefly the infective complications associated with blood transfusions, (2) Re-examine the indications for homologous blood products (HBP), and (3) Discuss some of the alternative strategies available to decrease or avoid the transfusion of HBP altogether. Special attention will be given, throughout the text, to the Canadian situation.

\section{Infective complications of blood transfusion}

The numerous complications of homologous blood transfusions have been reviewed extensively ${ }^{3,4}$ and are presented in Table I. The infective risk of blood transfusions appears to have declined recently as a result of screening policies for donated blood (Table II) implemented by the Blood Services of The Canadian Red Cross Society. ${ }^{7}$

In general, bacterial contaminants do not present a problem, except in platelet components which are stored at room temperature and for Yersinia enterolitica for which the storage temperature of $4^{\circ} \mathrm{C}$ is not as bacteriostatic as with other genera. Parasites are not a severe problem in Canada. Despite the awareness surrounding the transmission of AIDS by transfusion, the commonest infection associated with HBP is posttransfusion hepatitis (PTH); hepatitis A virus, cytomegalovirus and EpsteinBarr virus seldom cause PTH.

In the U.S.A., the frequency of PTH with the hepatitis $B$ virus is estimated to be 1 in 50,000 per recipient or approximately 1 in 200,000 per unit. ${ }^{8}$ Ninety percent have a self-limited .course (the majority, asymptomatic), five to ten percent will progress to a chronic state (half become asymptomatic carriers), and $1 \%$ will have a fulminant form of hepatitis (mortality $>50 \%$ ). In Canada, the numbers are similar. During the past three years, only one case of Hepatitis B-PTH has been reported by the Montreal Blood Centre for 900,000 blood products transfused (Gilles Delage, Canadian Red Cross Society Blood Centre in Montréal, personal communication). Assuming that only $25 \%$ of infections are symptomatic, this results in an infection rate similar to that reported in the U.S.A.

Hepatitis $\mathrm{C}$ virus (HCV) is the agent responsible for most, but probably not all, cases of non A/non B PTH. As for hepatitis B, the incidence of $\mathrm{HCV}$ associated PTH varies according to the population studied. Again, in Canada, the infection rate appears to be similar to that in the U.S.A. (Gilles Delage, personal communication), i.e., approximately 1 in 3000 blood components transfused. ${ }^{9}$ Hepatitis $\mathrm{C}$ posttransfusion hepatitis has a mild presentation initially, but $50 \%$ of patients progress to a chronic state (persistent carrier stage) and $10-20 \%$ of these develop cirrhosis.

In 1992, Crosby reported that presently only two HIV conversions (from 15 million units of blood products administered) have been associated with transfusions since the implementation of HIV screening in 1985 in Canada. ${ }^{3}$ The commonly used screening technique is based on the detection of antibodies to the HIV virus. Antibody negativity lasts eight weeks on average after infection, but seroconversion may be delayed for up to $42 \mathrm{mo}$. Therefore, a few contaminated units will continue to escape detection despite systematic screening. ${ }^{10}$ Nevertheless, with the present selection of donors and testing of blood, the risk of HIV transmission by blood transfusion is estimated between $1 / 40,000$ to $1 / 1,000,000$. "

Both HTLV-1 and HTLV-2 may cause leukaemia, lymphoma, tropical spastic paraparesis and HTLV-1 associated myelopathy. In Northern America, the transmis-

From the Departments of Anaesthesia and Haematology of the Université de Montréal, Montreal Heart Institute, 5000 Bélanger Est, Montréal, PQ, H1T 1 C8. 
TABLE I Classification of transfusion reactions ${ }^{3-5}$

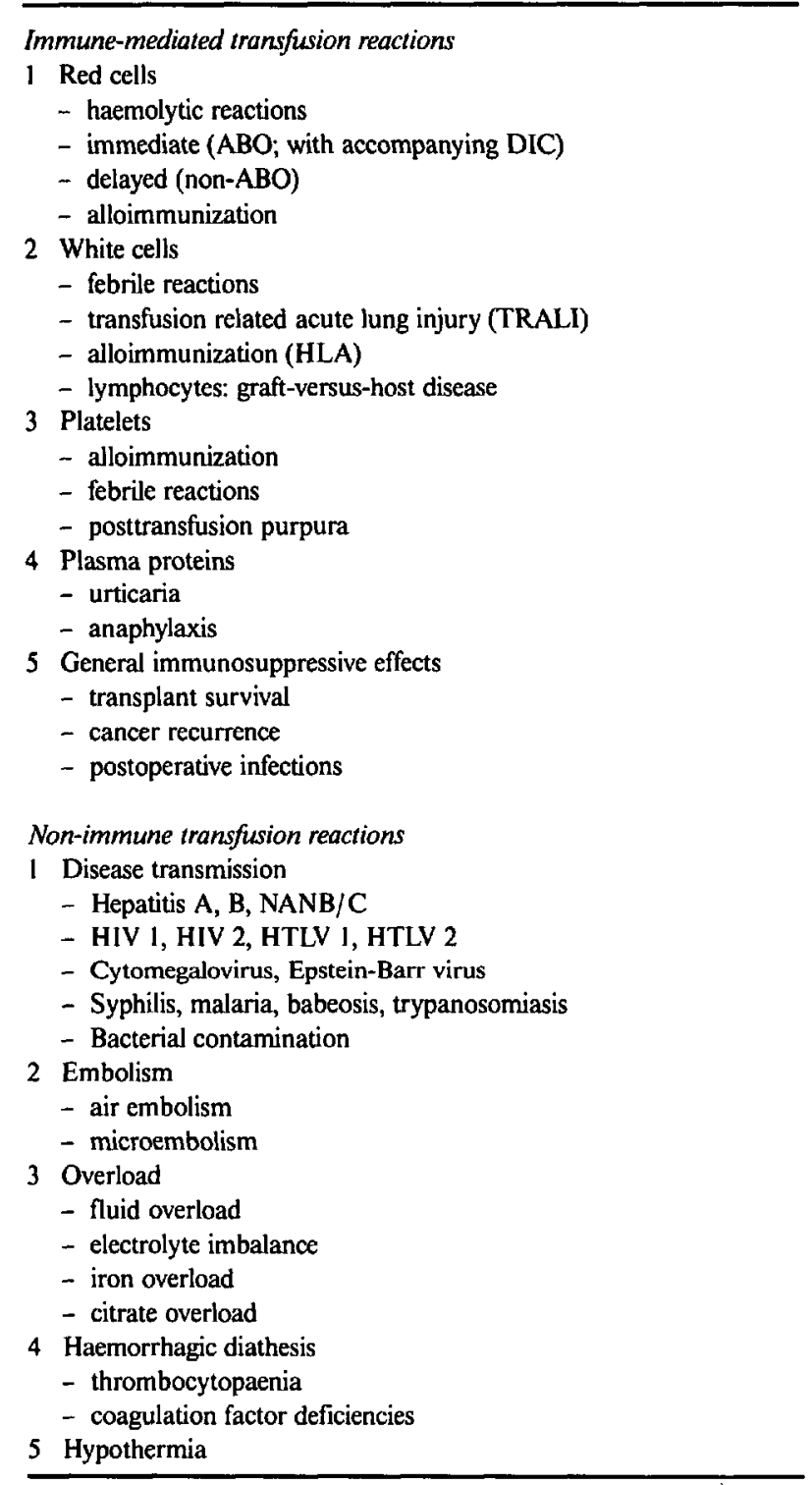

sion of HTLV is infrequent and the associated risks are difficult to assess at present.

Overall, it has been suggested that about 3 in 10,000 blood recipients contract serious or fatal viral disease transmitted by transfusion. ${ }^{8}$ As stated by the Canadian Red Cross Society, "transfusion of blood and blood products is associated with certain risks that cannot be predicted or prevented. The physician should prescribe transfusion only when it is clinically essential and when no other form of treatment would be as effective."7

\section{Indications for homologous blood products}

One unit of whole blood $(450 \mathrm{ml}$ in $63 \mathrm{ml}$ of anticoagulant) is separated into components within four to six
TABLE II Selection of donors and testing of donations in Canada

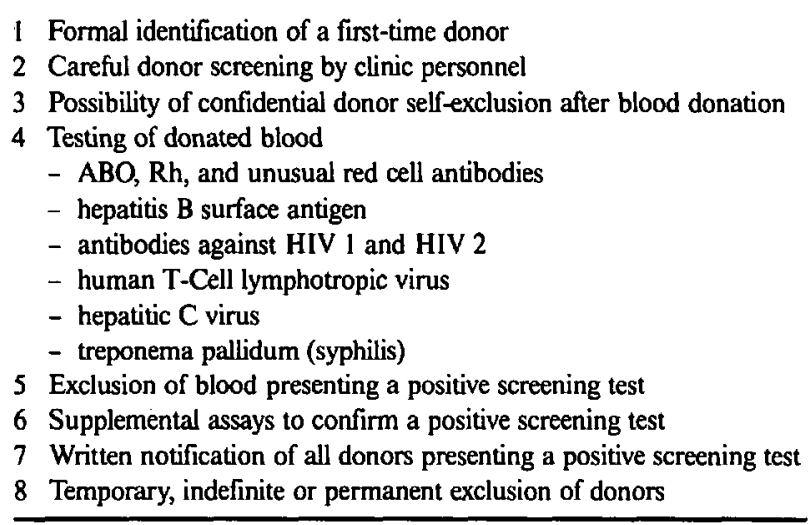

hours of donation. Separation allows each component to be stored under optimal conditions and patients can be administered only that portion of blood required by their condition, allowing several patients to benefit from a single donation. Of all the components derived from whole blood and available from the Red Cross (Table III), red blood cells (RBC), fresh frozen plasma (FFP) and platelets are, in essence, the only HBP that are administered commonly by anaesthetists and carry an infectious potential. The indications for these HBP will be reviewed on the basis of the Consensus Development Conferences convened by the Office of Medical Applications of Research, of the National Institutes of Health (USA). ${ }^{11-13}$

\section{Indications for the transfusion of $R B C$}

Red blood cells are prepared by removing supernatant plasma from a whole blood donation after centrifugation. One unit of RBC contains $200 \mathrm{ml}$ of red cells, with either the anticoagulant CPDA-1 or CP2D and $100 \mathrm{ml}$ of the additive AS-3 (Nutricel $⿴ 囗 十)$, and 90 or $60 \mathrm{ml}$ of plasma, respectively. Shelf life is 35 days at $1^{\circ}-6^{\circ} \mathrm{C}$, but $\mathrm{RBC}$ with AS-3 have the potential for $\mathbf{4 2}$ days shelf life. Isotonic saline may be added to either preparation to increase the flow of RBC. Red blood cells must be administered through a $170 \mu \mathrm{g}$ filter.

The Conference recognizes there is no evidence to support the use of a single criterion for transfusion, such as a haemoglobin concentration of $<100 \mathrm{~g} \cdot \mathrm{L}^{-1}$. "The decision to transfuse a specific patient should take into consideration the duration of anaemia, the intravascular volume, the extent of operation, the probability for massive blood loss, and the presence of coexisting conditions such as impaired pulmonary function, inadequate cardiac output, myocardial ischaemia, or cerebrovascular or peripheral circulatory disease." 11 The need for research to define the best indications for red blood cell transfusion is acknowledged. While "no single measure can replace 
TABLE III Blood components available from the Canadian Red Cross

Cellular components of blood
1 Red blood cells
2 Leukocytc depleted red blood cells
3 Deglycerolized red blood cells
4 Platelets from whole blood random donors
5 Platelets, apheresis from single donor
6 Leukocytes, apheresis

Plasma and plasma components

1 Plasma

2 Fresh frozen plasma

3 Cryoprecipitated AHF (antihaemophilic factor)

Plasma fractionation products

1 Blood volume expanders: albumins

2 Coagulation factor concentrates

- factor VIII

- porcine factor VIII:C

- factor IX complex (human) vapour treated

- coagulation factor IX (human) high purity

- anti-inhibitor coagulant complex, vapour heated: FEIBA

- factor VII concentrate $\left(^{*}\right)$

- special coagulation products $(\dagger)$

- fibrinogen; AT-III concentrate: Humate P; factor XI concentrate; factor XIII concentrate; protein $C$ concentrate.

3 Immune globulin preparations

- immune serum globulin: intramuscular

- varicella-zoster immune globulin

- hepatitis B immune globulin (human)

- immune globulin intravenous: intravenous

- Rho(D) immune globulin

- CMV hyperimmune globulin (*)

- special products $(\dagger)$ : $\mathrm{Cl}$ esterase inhibitor

*Require an Emergency Drug Release.

$\dagger$ Require an Emergency Drug Release and Canadian Blood Agency approval.

good clinical judgment as the basis for decisions regarding perioperative transfusion," $"$ is it possible to refine our criteria for transfusion of RBC any further?

The dominant role of RBC is the transport and delivery of oxygen from alveoli to cells. In acute blood loss, it is well accepted that volume replacement is more critical than the composition of the replacing fluids. Thus, RBC should not be administered for volume replacement alone, but only for the anaemia and decreased oxygen carrying capacity of the blood that accompanies severe haemorrhage. While transfusion of RBC is used to increase tissue oxygen delivery $\left(\mathrm{DO}_{2}\right)$, effective $\mathrm{DO}_{2}$ is dependent on the cardiovascular condition of the patient also. Higher than normal values for cardiac index and tissue oxygen consumption $\left(\mathrm{V}_{2}\right)$ are other important determinants of survival in patients with medical or surgical shock. ${ }^{14}$

During normovolaemic haemodilution (anaemia without hypovolaemia) blood viscosity decreases as the haematocrit is reduced and, between haematocrits of 28 and $45 \%, \mathrm{DO}_{2}$ remains relatively constant. ${ }^{5}$ When the haematocrit is decreased further, $\mathrm{VO}_{2}$ is maintained within normal limits by increasing either the cardiac output or the oxygen extraction ratio (ER). The increase in ER is somewhat limited by an already high ER in the cerebral and coronary circulations $(55-70 \%$ vs $25 \%$ total body ER) but, during progressive normovolaemic haemodilution in baboons, the global oxygen ER must exceed $50 \%$ for the myocardium to switch from lactate consumption to lactate production. ${ }^{15}$ Older patients and patients with coronary artery disease may not be able to increase cardiac output to compensate for anaemia. ${ }^{5}$ When compensatory mechanisms are no longer adequate, $\mathrm{VO}_{2}$ decreases and tissues survive by anaerobic metabolism.

In their extensive review of the literature since 1966, Welch et al. noted the remarkable tolerance of healthy patients to low haemoglobin concentrations (between 50 and $70 \mathrm{~g} \cdot \mathrm{L}^{-1}$ ), and suggested that clinicians can accept haemoglobin levels $>70 \mathrm{~g} \cdot \mathrm{L}^{-1}$ in most patients with selflimited anaemia. ${ }^{16}$ The conclusions of the Consensus Conference on perioperative red blood cell transfusion are not as explicit, but their findings point to the same recommendation. "The ASA Committee on Transfusion Medicine states that postoperative haemoglobin concentrations in the 60 to $80 \mathrm{~g} \cdot \mathrm{L}^{-1}$ range appear to be safe for patients free of cardiovascular disease. ${ }^{17}$ However, it must be recognized that the margin of safety for $\mathrm{DO}_{2}$ diminishes as haemoglobin concentrations decrease and patients with severe cardiovascular disease may not tolerate haemodilution below a haemoglobin value of 80 to $100 \mathrm{~g} \cdot \mathrm{L}^{-1} \cdot{ }^{17,18}$ Nevertheless, the effects of transfusion for anaemia on myocardial oxygen metabolism are not limited to the correction of the decreased oxygen supply, and clinicians must also take into account the possible aggravation of ischaemia by increasing blood volume, afterload, and blood viscosity. ${ }^{16}$ Haemodilution to an haematocrit of approximately $15 \%$ is well tolerated in anaesthetized humans after coronary artery bypass surgery, with no ECG or metabolic evidence of myocardial ischaemia. ${ }^{19}$

The absolute concentration of haemoglobin is not the only indicator of the need for transfusion of RBC. Surgical blood loss is also a strong and independent predictor of outcome. In a study of 125 patients who declined blood transfusion for religious reasons, no patient with a haemoglobin value of $>80 \mathrm{~g} \cdot \mathrm{L}^{-1}$ and an operative blood loss of $<500 \mathrm{ml}$ died. Mortality increased from $8 \%$ to $43 \%$ as blood loss increased from less than $500 \mathrm{ml}$ to over $2000 \mathrm{ml}$ despite maintenance of an adequate circulating volume. ${ }^{20}$

The efficacy of RBC transfusion should be monitored since the oxygen content of blood is not the only de- 
terminant of $\mathrm{DO}_{2}$ and $\mathrm{VO}_{2}$. It is interesting to note that, in dogs, moderate haemodilution to an haematocrit of 20 or $30 \%$ is associated with an improvement of the $\mathrm{O}_{2}$ extraction capabilities of the body (lower critical $\mathrm{DO}_{2}$ and higher critical $\mathrm{O}_{2}$ extraction ratio) during haemorrhage, compared with haemorrhage at an haematocrit of $40 \%{ }^{21}$ A useful endpoint to guide appropriateness of RBC administration is the increase of $\dot{\mathrm{VO}}_{2}$ in response to transfusion. A practical limitation of this recommendation is that measurement of $\dot{\mathrm{VO}}_{2}$ entails the use of invasive haemodynamic monitoring. However, increasing blood lactate concentration is an early indicator of inadequate perfusion and evidence of an oxygen debt. With the newer automated blood gas analysers, serum lactate levels are readily available and provide a valid and minimally invasive marker of anaerobic metabolism. An abrupt increase in blood lactate levels is observed when $\mathrm{DO}_{2}$ decreases below the critical $\mathrm{DO}_{2}$ value. ${ }^{21}$ Thus, lactate levels may prove to be a useful indicator of the need for adequacy of RBC transfusions, at least in certain patient subgroups. ${ }^{22}$

Another, less well known, function of red cells is to increase the platelet-to-platelet interaction and facilitate the interaction of platelets with the subendothelium. Transfusion of RBCs normalizes the bleeding time in anaemic-thrombocytopaenic patients despite persistent thrombocytopaenia. ${ }^{23}$ Similarly, RBCs control the haemorrhagic diathesis and shorten the bleeding time of uremic patients. ${ }^{24}$ Thus a haemoglobin concentration acceptable for maintenance of $\mathrm{DO}_{2}$ may not be sufficient to achieve optimal haemostasis. This may help to explain why, after cardiopulmonary bypass (CPB), the haemostatic effect of a single unit of fresh whole blood is at least equal, if not superior, to the effect of ten units of platelets. ${ }^{25}$

\section{Indications for transfusion of platelets ${ }^{7,13,17}$}

In the anaesthetic/surgical setting, platelet concentrates are the second most useful HBP after RBC. One unit of platelets is obtained following centrifugation of one unit of fresh whole blood. Platelets are concentrated in $30-50 \mathrm{ml}$ of plasma and the final product contains a small number of leucocytes and RBC (up to $0.4 \mathrm{ml}$ per unit). Storage at room temperature $\left(20^{\circ}-24^{\circ} \mathrm{C}\right)$ preserves function and slow constant horizontal agitation prevents the formation of platelet aggregates. Storage is restricted to five days to limit the growth of any contaminating bacteria. In the normal adult, administration of one unit of platelet concentrate increases the platelet count by $5-10$ $\times 10^{9} \cdot \mathrm{L}^{-1}$ one hour after transfusion. Thus, the usual dose consists of six to eight units of platelets and exposes the recipient to an equivalent number of donors. Platelet units can be mixed in a single bag prior to administration (but must then be administered within six hours), and use of a standard $170 \mu \mathrm{m}$ filter is recommended. Administration of $A B O$ incompatible platelets is an accepted practice. Even with the administration of $A B O$ compatible platelets, the possibility of $\mathrm{Rh}$ immunization must be considered in female patients of child-bearing age. Red cell haemolysis may also occur when large numbers of ABO incompatible platelet concentrates are transfused. Special circumstances may dictate the use of platelets obtained from random or HLA-matched single donors.

Patients with severe thrombocytopaenia may benefit from platelet transfusion to prevent bleeding. The empirical value of $20 \times 10^{9}$ platelets $\cdot \mathrm{L}^{-1}$ is usually considered adequate in the medical setting. Patients with chronic thrombocytopaenia generally do not require routine platelet transfusions but may benefit from prophylactic administration of platelets prior to surgery or other invasive procedures. Consultation with a haematologist is suggested to determine the optimal platelet count for each patient since, for example, other options such as administration of immunoglobulins $i v$ may normalize the platelet count in idiopathic thrombocytopaenic purpura.

As a general rule, blood components administered to improve haemostasis, such as platelet concentrates and FFP, should never be given for abnormal laboratory studies in the absence of clinical bleeding. Patients with thrombocytopaenia and/or an abnormality of platelet function who are bleeding should receive platelets, if the platelet disorder is likely to be causing or contributing to the bleeding. ${ }^{13}$ A reasonably accurate platelet count may be obtained very rapidly with an automated blood counter. In the absence of platelet dysfunction, a platelet count of $50 \times 10^{9} \cdot \mathrm{L}^{-1}$ or higher is unlikely to be responsible for active bleeding. Evaluation of platelet function is much more difficult and, at present, there is no consensus as to the ideal method of evaluation. Appearance of the surgical wound, template bleeding time, thromboelastography, and analysis of the Sonoclot Signature ${ }^{\circledR}$ may provide some indication of platelet function.

Massive transfusion is usually defined as the acute administration of more than one blood volume within several hours and may lead to coagulopathy characterized by microvascular bleeding (a typical, generalized oozing), usually after transfusion of 15-20 units of RBCs in previously healthy adults. ${ }^{26,27}$ In order of frequency, coagulation defects result from (1) Loss of platelets and, very rarely, labile factors V and VIII; (2) Disseminated intravascular coagulation (DIC) associated with shock; and (3) Haemolytic transfusion reactions. ${ }^{13}$ Platelet release by the spleen and bone marrow helps to prevent dilutional thrombocytopaenia but, in the presence of microvascular bleeding, a platelet count of $<50$ to $100 \times 10^{9} \cdot \mathrm{L}^{-1}$ can be considered an indication for platelet transfusion. ${ }^{26,27}$ 
The indications for transfusion of platelets after CPB are not any different and there is no justification for the prophylactic administration of platelets in patients undergoing open heart surgery.

When bleeding does not resolve with platelet transfusion, the next logical step is to administer FFP. ${ }^{28}$

\section{Indications for the transfusion of FFP 7,12,17}

After platelets have been separated, the remaining platelet-poor plasma is rapidly frozen to prevent inactivation of temperature sensitive ("labile") coagulation factors $\mathrm{V}$ and VIII. One unit of FFP has a volume of $190-260 \mathrm{ml}$ and is stored at a temperature of $<-18^{\circ} \mathrm{C}$. Few specific indications for the use of FFP exist. There is no justification for the use of FFP for volume replacement or for nutritional support. There is no evidence that FFP has a beneficial effect when used as part of the transfusion management of patients with massive haemorrhage.

Fresh frozen plasma contains all the coagulation factors found in plasma, at a level of activity close to normal, and is indicated for the treatment of isolated factor deficiencies when specific component therapy is either unavailable or inappropriate. Consultation with a haematologist is recommended to determine the most appropriate therapy in this context.

The functional deficiencies induced by oral anticoagulants can be reversed by vitamin $K$ but, when these patients bleed actively or present for emergency surgery, FFP can be used to achieve immediate haemostasis. Subcutaneous vitamin $\mathrm{K}$ will take 6 to $24 \mathrm{hr}$ to normalize the coagulation defect. Fresh frozen plasma may be efficacious in massively transfused patients who are bleeding actively, when factor deficiencies are thought to be contributing to the coagulopathy. However, in this situation, clinicians must acknowledge that haemorrhage is caused more frequently by thrombocytopaenia. The Consensus Conference recognized that circumstances exist in which FFP has been employed and is believed to be of therapeutic value (e.g., multiple coagulation protein deficiencies in the uncontrollably bleeding patient), but data supporting its efficacy are limited or unavailable. Again, there is no evidence to support the prophylactic administration of FFP in patients receiving multiple RBC transfusions.

Finally, FFP may be useful as a source of antithrombin III, for the treatment of specific immunodeficiencies, and for the treatment of thrombotic thrombocytopaenic purpura.

In the presence of active bleeding, when FFP is indicated, large volumes (four to eight units) given rapidly are necessary to result in clinically important increases in serum levels of coagulation factors. ${ }^{29}$ In the absence
TABLE IV Strategies to reduce the need for homologous blood products in the perioperative period

1 Before surgery

- avoid unnecessary preoperative phlebotomies

- avoid/stop drugs affecting coagulation: e.g., ASA, NSAID

- recombinant human erythropoietin to increase haemoglobin level/yield of autologous predonation

- informed consent for transfusion?

2 Approaches to reduce blood loss intraoperatively

- meticulous surgical technique

- maintenance of normothermia

- ancillary techniques

- tourniquet

- local infiltration with epinephrine

- adequate venous drainage of operative site

- controlled hypotension

- pharmacological agents

- desmopressin (DDAVP)

- natural and synthetic antifibrinolytics

3 Measures to decrease the risks of anaemia

- reduction of $\mathrm{O}_{2}$ consumption

- anaesthesia/sedation

- mechanical ventilation

- prevention of shivering

- optimization of the function of circulating haemoglobin

- increased $\mathrm{O}_{2}$ transport: supplemental $\mathrm{O}_{2}$ to increase $\mathrm{PaO}_{2}$

- maintenance of a normal $\mathrm{O}_{2}$-haemoglobin dissociation curve: - attention to normothermia

- avoidance of metabolic alkalosis and hyperventilation

4 Alternatives to homologous red cells (from random donors)

- mindfulness and education

- tolerance of low haemoglobin concentrations

- autologous transfusions

- preoperative donation

- intraoperative donation: normovolaemic haemodilution

- intra- and postoperative retransfusion of shed blood

- directed donations

- blood substitutes

of active bleeding, two units of FFP are sufficient to reverse the effect of warfarin or coumadin if urgent reversal of anticoagulation is indicated. However, this effect is transient (6-8 hr) and coagulopathy will recur if vitamin $\mathrm{K}$ has not been administered.

\section{Avoiding homologous blood products}

Numerous strategies have been explored and are recommended to decrease or eliminate the need for transfusion of HBP (Table IV). Some are relatively benign, but others carry risks that must be weighed against those involved when transfusing HBP to a given patient population.

\section{Preoperative strategies}

Nonsteroidal anti-inflammatory drugs (NSAID), ${ }^{30}$ acetylsalicylic acid (ASA), ${ }^{31}$ and perhaps some calcium channel antagonists, ${ }^{32}$ are associated with increased post- 
operative bleeding and should be discontinued, if possible, before elective surgery, or replaced by agents with short half-lives whenever possible.

Recombinant human erythropoietin is being used currently to treat patients with renal failure and other diseases that result in chronic anaemia. Preoperative administration of erythropoietin, in combination with autologous blood predonation, reduces transfusion of HBP in patients undergoing cardiac operations. ${ }^{33,34}$ Erythropoietin is expensive and side effects such as hypertension and hyperviscosity are of concern. It has been recommended that its use be limited to patients who are anaemic before donation (haematocrit $<36 \%$ ) or who are of low body weight $\left(<52 \mathrm{~kg}\right.$ ). ${ }^{35}$ In addition to augmenting the level of circulating erythrocytes, erythropoietin may help prevent the impairment of immune function that occurs after cardiac surgery. ${ }^{36}$

Given the risks associated with HBP, it has been suggested that informed consent be obtained before transfusion, ${ }^{37}$ but opinions differ about the advisability of obtaining a written informed consent. ${ }^{17}$ Certainly, the anaesthetist should document in the anaesthesia record the indications for administration of blood products. ${ }^{17}$ In California, the Paul Gann Blood Safety Act mandates that patients be informed of the risks of blood transfusion and alternatives to it. The Act appears to have prompted increased attention to currently available methods of blood salvage and conservation, lessened blood losses through improved surgical technique, and resulted in reduced transfusion of HBP in patients undergoing cardiac surgery. ${ }^{38}$

\section{Approaches to reduce blood loss intraoperatively}

Intraoperatively, a number of techniques have long been available to reduce blood loss. These include application of a tourniquet, local infiltration with an epinephrinecontaining solution, optimal venous drainage of the operative site, controlled hypotension and, most important of all, meticulous surgical technique. It has also been shown that variable stress control by anaesthesia may modify haemostasis in cardiac surgical patients, but the effects on blood loss and requirements for HBP remain unclear. ${ }^{39}$

Another important, less emphasized, measure to reduce blood loss through preservation of haemostasis is the maintenance of normothermia. Hypothermia causes a reversible platelet dysfunction and rewarming improves platelet function and reduces both bleeding time and blood loss after CPB. ${ }^{40}$ The same authors suggested that rewarming should be attempted before administering HBP in hypothermic bleeding patients, whether it be after $\mathrm{CPB}$, operation, or trauma. ${ }^{40}$ Also, hypothermia strongly inhibits the enzymatic reactions of the coagulation cas- cade and, in the presence of a bleeding patient, this additional contribution of hypothermia to the haemorrhagic diathesis may be overlooked since coagulation testing is performed at $37^{\circ} \mathrm{C} .41$

Pharmacological reduction of bleeding associated with surgery, especially with $\mathrm{CPB}$, has received much attention. ${ }^{42,43}$ It has the advantage of being readily available and easy to administer, of avoiding the use of costly equipment, and it may be used prophylactically rather than therapeutically in some instances. Desmopressin (DDAVP), a vasopressin analogue, epsilon-aminocaproic acid (EACA) and tranexamic acid (TA), two synthetic antifibrinolytics, and aprotinine (Apt), an antifibrinolytic derived from bovine lung, have been used either to diminish or to prevent excessive bleeding associated with cardiac and other major, complicated, surgery.

In 1986, Salzman et al. demonstrated a reduction of blood loss after cardiac surgery by DDAVP in a doubleblind, prospective, placebo-controlled, randomized trial. ${ }^{44}$ Numerous subsequent studies by different authors using a similar protocol have failed to reproduce these results. A likely explanation is that blood loss in the original study was excessively high and that Salzman's results may not be generalized to other centres where blood loss is much lower. While thromboelastographic assessment of coagulation may help to identify a subgroup of patients where DDAVP is likely to be efficacious, ${ }^{45}$ the usefulness of DDAVP in cardiac surgery is still a subject of controversy ${ }^{46,47}$ Similarly, there is no agreement as to the efficacy of DDAVP to reduce surgical bleeding in patients undergoing spinal fusion for scoliosis. ${ }^{48,49}$ Furthermore, DDAVP seems to carry a risk of thrombosis and it should be used cautiously in elderly patients and in those with atherosclerosis. ${ }^{50,51}$

The prophylactic administration of EACA and TA has been restricted largely to cardiac surgery and haemophiliac patients undergoing minor surgical procedures. Retrospective data collected on 411 patients at the Toronto Hospital show that $10 \mathrm{~g}$ TA reduced post-CPB bleeding in the first $24 \mathrm{hr}$ prevented excessive bleeding $>750 \mathrm{ml}$ in six hours), and reduced the number of patients receiving HBP. ${ }^{52}$ Other data from the same institution demonstrated that TA, EACA and normothermic perfusion are equally effective in reducing postoperative blood loss and in preserving platelets. ${ }^{53}$ Thus, more data are necessary to define the optimal dose and the clinical effectiveness of these drugs in cardiac surgery. Both EACA and TA are equally effective to treat fibrinolysis and control the bleeding diathesis associated with liver transplantation, but the prophylactic use of these agents is not recommended, to avoid thrombotic complications. ${ }^{54}$

Aprotinin is a polypeptide of 58 amino acid residues which inhibits a wide range of serine proteases. In addi- 
tion to the antiplasmin (antifibrinolytic) action it shares with EACA and TA, aprotinin also inhibits kallikrein and the stimulation of the coagulation cascade secondary to the liberation of tissue plasminogen activator. This dual action of aprotinin is thought to be responsible for its generally accepted efficacy in cardiac surgery. ${ }^{42}$ It has also been used successfully in the management of abruptio placentae with disseminated intravascular coagulopathy, ${ }^{55}$ to prevent rebleeding after subarachnoid haemorrhage, ${ }^{56}$ and to reduce bleeding after orthopaedic [John Murkin, personal communication] and vascular surgery. ${ }^{57}$ Many centres are now administering routinely prophylactic aprotinin in high doses ( 2 million KIU loading dose, followed by an infusion of $500,000 \mathrm{KIU} \cdot \mathrm{hr}^{-1}$ ) to reduce perioperative bleeding and HBP requirement during liver transplantation 58,59 and cardiac surgery (two million KIU are also added to the priming fluid of the CPB circuit). ${ }^{60}$ Administration of aprotinin may be associated with minor allergic responses or anaphylaxis, especially when administration is repeated, but the risk is small $(<1 \%){ }^{61}$ Despite fears that high doses of aprotinin may increase thrombotic complications, the safety record of aprotinin, to date, is impressive. ${ }^{62,63}$

\section{Measures to decrease the risks of anaemia}

These are well known to anaesthetists and do not warrant a more detailed discussion. They can alleviate the physiological consequences of anaemia while confirmatory evidence for the need to transfuse is being sought.

\section{Perioperative alternatives to homologous red cells}

Despite all efforts to reduce blood loss, transfusion of red cells may become necessary but, even then, a number of strategies may decrease the need for homologous blood. First, those who order transfusions should do so mindfully rather than automatically, in response to a pathophysiological trigger. Attention to a set of arbitrary criteria rather than to the patient's needs explains the great variability of transfusion practice in coronary bypass surgery. ${ }^{64}$ "The patients know this (practice) is not acceptable; we must realize it too. Blood and blood products should be given only when there are clear indications. ${ }^{\text {655 }}$ It follows that all those who order transfusions must be educated about the indications and risks involved.

Tolerance of low haemoglobin concentrations has been discussed and is the first step toward reducing exposure to HBP. Although the limits of haemodilution remain to be defined, transfusions guided by clinical indications while allowing the haematocrit to decrease to $<25 \%$ resulted in fewer RBC requirements, similar exercise tolerance and no adverse clinical consequences compared with transfusions aimed at maintaining the haematocrit above $32 \%$ in patients undergoing myocardial revascularization. ${ }^{6}$

Autologous blood predonation remains underused, but should be considered before all elective procedures for which blood would be crossmatched normally. Autologous donation decreases the need for HBP in part because physicians tolerate lower haemoglobin concentrations in patients who are autologous donors. ${ }^{67}$ Autologous blood is immunologically identical to the recipient and is the safest possible transfusion product. Thus, autologous blood is transfused somewhat more liberally, but it should be administered only when signs or symptoms of anaemia are present to avoid volume overload and hyperviscosity. The risk of administering an incompatible transfusion secondary to a clerical error is always present. A programme for preoperative donation is in place at the $\mathrm{Ca}$ nadian Red Cross Blood Centre's permanent clinic site. ${ }^{7}$ Patients may donate a unit of blood weekly for a maximum of four units. All patients may be considered, but specialized centres will be required for high risk donors with severe cardiovascular disease. Autologous units are identified with a specific green "autologous only" tag and should be checked as carefully as for HBP. Currently, these units are not transfused to other patients.

In the absence of predonation, other autologous techniques may still be used. Normovolaemic haemodilution (NH) is effective, save, and easy to implement. ${ }^{68}$ Under sterile conditions, blood is withdrawn from a central or large peripheral vein, or an artery, into bags containing anticoagulant. The volume of blood to be removed depends on the patient's estimated blood volume (EBV), initial haematocrit (Hi) and desired (final) haematocrit (Hf), and is calculated as follows:

Volume to be removed $=\mathrm{EBV} \times \frac{\mathrm{Hi}-\mathrm{Hf}}{\mathrm{Hm}}$

where $\mathrm{Hm}$ is the mean of $\mathrm{Hi}$ and $\mathrm{Hf}$ and allows for correction for ongoing dilution. ${ }^{69}$

Normovolaemia must be maintained strictly. Crystalloids or colloids may be chosen, depending on the patient's underlying condition and his capacity to handle fluid shifts. Each unit of blood collected is labeled carefully and kept at room temperature (up to six hours) to preserve platelet function. The blood is reinfused whenever necessary, preferably when major blood loss is controlled. The main contraindication to NH is anaemia. Coronary artery disease does not preclude $\mathrm{NH}$, but ischaemia or haemodynamic instability may limit the volume of blood that can be removed safely. ${ }^{70}$

Intraoperative salvage of RBC using automated blood collecting and washing equipment has been shown to be useful in cardiac, vascular, orthopaedic, and trauma surgery. ${ }^{71}$ Potential complications are numerous and in- 
clude coagulopathy when large volumes of washed cells are reinfused. However, the major drawbacks to this technique are the high costs, both in equipment and personnel, required to operate these blood salvaging systems. ${ }^{68,71}$

After cardiac surgery, shed mediastinal blood can be collected in the same cardiotomy reservoir used during CPB and retransfused to the patient. While this approach is economical and can contribute to reduced transfusions of $\mathrm{RBC},{ }^{72}$ it may become counterproductive when surgeons rely on the technique to the detriment of meticulous haemostasis.

In Canada, blood from friends or relatives selected by a patient for their own use is not collected by the $\mathrm{Ca}$ nadian Red Cross Society. Directed donations are used only for matching of rare blood types or for transfusing platelets to a refractory patient. ${ }^{7}$ In the United States, many blood centres have started designated donor programmes in response to public pressure or state laws, but several arguments militate against the concept: the increased safety of blood obtained from designated donors remains unproven; an additional clerical burden is imposed on the blood banking system; regular blood supplies may decrease if routine donors refrain from donating blood in order to remain available for specific patients. ${ }^{17}$ Furthermore, directed donations from family members carry a risk of graft-vs-host disease if the donor is homozygous for an HLA haplotype shared with the recipient. ${ }^{73}$ This situation has now also been reported in unrelated donors. ${ }^{74}$

Finally, synthetic oxygen transport media are being developed to reduce the requirements for RBC during the perioperative period. ${ }^{5}$ These substitutes are not in clinical use and will not be discussed further.

\section{Conclusion}

Despite the complications associated with transfusions, HBP remains an essential therapeutic modality, without which many major surgical procedures would be impossible. Clinicians must realize that transfusion of HBP is the most frequent transplantation of living tissue between humans. Even if known infectious complications could be eliminated, transfusion of HBP will never be a totally safe procedure. New transfusion-related complications, the magnitude of which is unknown, such as graft-vshost disease in immunocompetent patients, have emerged recently. Other, as yet unidentified, pathogens will undoubtedly be transmitted by HBP in the future.

A number of strategies exist that can reduce, and sometimes abolish, the need for HBP. Unfortunately, some of these may remain unavailable to our patients because of financial constraints on the Canadian health care system. Nonetheless, physicians must always keep in mind that the first and foremost strategy to avoid transfusion of HBP is their thorough understanding of the pathophysiological mechanisms involved in anaemia and coagulopathy, and their thoughtful adherence to published guidelines for the practice of transfusion. ${ }^{7,11-13,17}$

\section{References}

1 Beal RW. The rational use of blood. Aust N Z J Surg 1976; 46: 309-13.

2 Surgenor DM, Wallace EL, Hale SG, Gilpatrick $M W$. Changing patterns of blood transfusion in four sets of United States hospitals, 1980 to 1985 . Transfusion 1988; 28: 513-8.

3 Crosby ET. Perioperative haemotherapy: II. Risks and complications of blood transfusion. Can J Anaesth 1992; 39: 822-37.

4 Ellison N. Faust RJ. Complications of blood transfusion. In: Benumof JL, Saidman LJ. (Eds.). Anesthesia and Perioperative Complications. St. Louis: Mosby Year Book 1992; 507-19.

5 Crosby ET. Perioperative haemotherapy: I. Indications for blood component transfusion. Can J Anaesth 1992; 39: 695-707.

6 Irving $G A$. Perioperative blood and blood component therapy. Can J Anaesth 1992; 39: 1105-15.

7 The Canadian Red Cross Society Clinical Guide to Transfusion. 3rd ed. 1993.

8 Dodd $R Y$. The risk of transfusion-transmitted infection (Editorial). N Engl J Med 1992; 327: 419-21.

9 Donahue JG, Muñ̃z A, Ness PM, et al. The declining risk of post-transfusion hepatitis $C$ virus infection. $N$ Engl $J$ Med 1992; 327: 369-73.

10 Nelson KE, Donahue JG, Muñ̃z A, et al. Transmission of retroviruses from seronegative donors by transfusion during cardiac surgery. A multicenter study of HIV-1 and HTLV-I/II infections. Ann Intern Med 1992; 117: 554-9.

11 Consensus Conference: Perioperative red blood cell transfusion. JAMA 1988; 360: 2700-3.

12 Consensus Conference: Fresh frozen plasma. Indications and risks. JAMA 1985; 253: 551-3.

13 Consensus Conference: Platelet transfusion therapy. JAMA 1987; 257: 1777-80.

14 Shoemaker WC. A stitch in time saves lives (Editorial). Chest 1993; 103: 663-4.

15. Wilkerson DK, Rosen AL, Gould SA, Sehgal LR, Sehgal $H L$, Moss GS. Oxygen extraction ratio: a valid indicator of myocardial metabolism in anemia. J Surg Res 1987; 42: 629-34.

16 Welch $H G$, Meehan KR, Goodnough LT. Prudent strategies for elective red blood cell transfusion. Ann Intern Med 1992; 116: 393-402.

17 American Society of Anesthesiologists Committee on 
Transfusion Medicine. Questions and answers about transfusion practices. 2nd ed. 1992.

18 Weisel RD, Charlesworth DC, Mickleborough LL, et al. Limitations of blood conservation. J Thorac Cardiovasc Surg 1984; 88: 26-38.

19 Mathru M, Kleinman B, Blakeman B, Sullivan H, Kumar $P$. Dries DJ. Myocardial metabolism and adaptation during extreme hemodilution in humans after coronary revascularization. Crit Care Med 1992; 20: 1420-5.

20 Carson JL, Poses RM, Spence RK, Bonavita G. Severity of anaemia and operative mortality and morbidity. Lancet 1988; 1: 727-9.

21 Van Der Linden P, Gilbart E, Paques P, Simon S, Vincent $J L$. Influence of hematocrit on tissue $\mathrm{O}_{2}$ extraction capabilities during acute hemorrhage. Am J Physiol 1993; 264: H1942-7.

22 Izraeli S, Ben-Sira L, Harell D, Naor N, Ballin A, Davidson $S$. Lactic acid as a predictor for erythrocyte transfusion in healthy preterm infants with anemia of prematurity. J Pediatr 1993; 122: 629-31.

23 Escolar $G$, Garrido $M$, Mazzara $R$, Castillo $R$, Ordinas $A$. Experimental basis for the use of red cell transfusion in the management of anemic-thrombocytopenic patients. Transfusion 1988; 28: 406-11.

24 Livio $M$, Benigni A, Remuzzi $G$. Coagulation abnormalities in uremia. Sem Nephrol 1985; 5: 82-90.

25 Mohr R, Martinowitz U, Lavee J, Amroch D, Ramot B, Goor $D A$. The hemostatic effect of transfusing fresh whole blood versus platelet concentrates after cardiac operations. J Thorac Cardiovasc Surg 1988; 96: 530-4.

26 Counts RB, Haisch C, Simon TL, Maxwell NG, Heimbach DM, Carrico CJ. Hemostasis in massively transfused trauma patients. Ann Surg 1979; 190: 91-9.

27 Reed RL 2nd, Ciavarella D, Heimbach DM, et al. Prophylactic platelet administration during massive transfusion. Ann Surg 1986; 203: 40-8.

28 Murray DJ, Olson J, Strauss R. Tinker JH. Coagulation changes during packed red cell replacement of major blood loss. Anesthesiology 1988; 69: 839-45.

29 Braunstein AH, Oberman HA. Transfusion of plasma components. Transfusion 1984; 24: 281-6.

30 Connelly CS, Panush RS. Should nonsteroidal antiinflammatory drugs be stopped before elective surgery? Arch Intern Med 1991; 151: 1963-6.

31 Bashein G. Nessly ML, Rice AL, Counts RB, Misbach $G A$. Preoperative aspirin therapy and reoperation for bleeding after coronary artery bypass surgery. Arch Intern Med 1991; 151: 89-93.

32 Becker RC, Caputo R, Ball S, Corrao JM, Baker S, Gore $J M$. Hemorrhagic potential of combined diltiazem and recombinant tissue-type plasminogen activator administrator. Am Heart J 1993; 126: 11-4.

33 Kyo S, Omoto R, Hirashima K, Eguchi S, Fujita T. Effect of human recombinant erythropoietin on reduction of homologous blood transfusion in open-heart surgery. A Japanese multicenter study. Circulation (Supplement) 1992; 86: II-413-8.

34 Konishi T, Ohbayashi T, Kaneko T, Ohki T, Saitou Y, Yamato $Y$. Preoperative use of erythropoietin for cardiovascular operations in anemia. Ann Thorac Surg 1993; 56: 101-3.

35 Nonoguchi $H$, Abe K, Komatsu $F$. Recombinant human erythropoietin for autologous blood donation (Letter). Lancet 1992; 339: 1483.

36 Hisatomi K, Isomura T, Galli SJ, Yasunaga H, Hayashida $N$, Ohishi $K$. Augmentation of interleukin-2 production after cardiac operations in patients treated with erythropoietin. J Thorac Cardiovasc Surg 1992; 104: 278-83.

37 Goodnough LT, Shuck JM. Risks, options, and informed consent for blood transfusion in elective surgery. Am J Surg 1990; 159: 602-9.

38 Carey JS, Cukingnan RA, Carson E. Transfusion therapy in cardiac surgery: impact of the Paul Gann Blood Safety Act in California. Am Surg 1991; 12: 830-5.

39 Kuitunen A, Hynynen M, Salmenperä, et al. Anaesthesia affects plasma concentrations of vasopressin, von Willebrand factor and coagulation factor VIII in cardiac surgical patients. Br J Anaesth 1993; 70: 173-80.

40 Valeri $C R$, Khabbaz K, Khuri SF, et al. Effect of skin temperature on platelet function in patients undergoing extracorporeal bypass. J Thorac Candiovasc Surg 1992; 104: 108-16.

41 Rohrer MJ, Natale AM. Effect of hypothermia on the coagulation cascade. Crit Care Med 1992; 20: 1402-52.

42 Royston $D$. High-dose aprotinin therapy: a review of the first five years' experience. J Cardiothorac Vasc Anesth 1992; 6: 76-100.

43 Hardy JF, Desroches $J$. Natural and synthetic antifibrinolytics in cardiac surgery. Can J Anaesth 1992; 39: 353-65.

44 Salzman EW, Weinstein MJ, Weintraub, et al. Treatment with desmopressin acetate to reduce blood loss after cardiac surgery. A double-blind randomized trial. N Engl J Med 1986; 314: 1402-6.

45 Mongan PD, Hosking MP. The role of desmopressin acetate in patients undergoing coronary artery bypass surgery: a controlled clinical trial with thromboelastographic risk stratification. Anesthesiology 1992; 77: 38-46.

46 Shiffrin JS, Glass DD. DDAVP administration for postbypass bleeding. Pro: desmopressin is of value in the treatment of post-cardiopulmonary bypass bleeding. $\mathrm{J}$ Cardiothorac Vasc Anesth 1991; 5: 285-9.

47 Hackman T, Naiman SC. Con: desmopressin is not of value in the treatment of post-cardiopulmonary bypass bleeding. J Cardiothorac Vasc Anesth 1991; 5: 290-3.

48 Kobrinsky NL, Letts RM, Patel LR, et al. 1-desamino-8$D$-arginine vasopressin (desmopressin) decreases operative 
blood loss in patients having Harrington rod spinal fusion surgery. A randomized double-blinded, controlled trial. Ann Intern Med 1987; 107: 446-50.

49 Guay J, Reinberg C, Poitras B, et al. A trial of desmopressin to reduce blood loss in patients undergoing spinal fusion for idiopathic scoliosis. Anesth Analg 1992; 75: 405-10.

50 Anonymous. Desmopressin and arterial thrombosis (Editorial). Lancet 1989; 938-9.

51 Mannucci PM, Lusher JM. Desmopressin and thrombosis (Letter). Lancet 1989; 675-6.

52 Karski JM, Teasdale SJ, Norman PH, Carroll JA, Weisel $R D$, Glynn MFX. Prevention of postbypass bleeding with tranexamic acid and E-aminocaproic acid. J Cardiothorac Vasc Anesth 1993; 7: 431-5.

53 Yau TM, Carson S, Weisel RD, et al. The effect of warm heart surgery on postoperative bleeding. J Thorac Cardiovasc Surg 1992; 103: 1155-63.

54 Kang $Y$. Clinical use of synthetic antifibrinolytic agents during liver transplantation. Sem Thromb Hemost 1993; 19: 258-61.

55 Sher G. Trasylol in the management of abruptio placentae with consumption coagulopathy and uterine inertia. J Reprod Med 1980; 25: 113-8.

56 Beck OJ, Oeckler $R$. Subarachnoid haemorrhage (Letter). BMJ 1982; 284: 1050.

57 Thompson JF, Roath OS, Francis JL, Webster JHH, Chant $A D B$. Aprotinin in peripheral vascular surgery (Letter). Lancet 1990; 335: 911.

58 Neuhaus P, Bechstein WO, Lefébre B, Blumhardt G, Slama $K$. Effects of aprotinin on intraoperative bleeding and fibrinolysis in liver transplantation (Letter). Lancet 1989; 924-5.

59 Grosse $H$, Lobbes $W$, Frambach $M$, von Broen $O$, Ringe $B$, Barthels $M$. The use of high dose aprotinin in liver transplantation: the influence on fibrinolysis and blood loss. Thromb Res 1991; 63: 287-97.

60 Dietrich W, Barankay A, Hähnel Ch, Richter JA. Highdose aprotinin in cardiac surgery: three years' experience in 1,784 patients. J Cardiothorac Vasc Anesth 1992; 6: 324-7.

61 Freeman JG, Turner GA, Venables CW, Latner $A L$. Serial use of aprotinin and incidence of allergic reactions. Curr Med Res Opin 1983; 8: 559-61.

62 Hardy JF, Belisle S. Aprotinin therapy for reoperative myocardial revascularization: an opposing view (Letter). Ann Thorac Surg 1993; 56: 198.

63 Murkin JM, Shannon NA, Bourne RB, Rorabeck CH, Cruickshank M. Aprotinin does not increase the risk of venous thrombosis in patients undergoing revision total hip joint replacement surgery. Anesthesiology 1993; 79: A58.

64 Goodnough LT, Johnston MFM, Toy PTCY, and the Transfusion Medicine Academic Award Group The variability of transfusion practice in coronary artery bypass surgery. JAMA 1991; 265: 86-90.
65 Myhre BA. To treat the patient or to treat the surgeon (Editorial). JAMA 1991; 265: 97-8.

66 Johnson RG, Thurer RL, Kruskall MS, et al. Comparison of two transfusion strategies after elective operations for myocardial revascularization. J Thorac Cardiovasc Surg 1992; 104: 307-14.

67 Wasman J, Goodnough LT. Autologous blood donation for elective surgery. Effect on physician transfusion behavior. JAMA 1987; 258: 3135-7.

68 Côté DJ. L'hémodilution normovolémique. Can J Anaesth 1991; 38: 243-51.

69 Gross $J B$. Estimating allowable blood loss: corrected for dilution. Anesthesiology 1983; 58: 277-80.

70 Schönberger JPAM, Bredée JJ, Tjian D, Everts PAM, Wildevuur $C R H$. Intraoperative predonation contributes to blood saving. Ann Thorac Surg 1993; 56: 893-8.

71 Stehling $L$. Autotransfusion and hemodilution. In: Miller RD (Ed.). Anesthesia, 3rd ed., New York: Churchill Livingstone Inc., 1990; 1501-13.

72 Ourum E, Am Holen E, Abdelnoor M, Oystese $R$. Conventional blood conservation techniques in 500 consecutive coronary artery bypass operations. Ann Thorac Surg 1991; 52: 500-5.

73 Thaler M, Shamiss A; Orgad S, et al. The role of blood from HLA-homozygous donors in fatal transfusionassociated graft-vs-host disease after open-heart surgery. $\mathrm{N}$ Engl J Med 1989; 321: 25-8.

74 Bell C. Fatal transfusion-associated graft-versus-host disease caused by blood from an unrelated donor in an immunocompetent patient. Transfusion 1993; 33: 785-6. 


\section{Du bon usage des dérivés du sang}

Jean-François Hardy MD FRCPC,

Sylvain Belisle MD FRCPC,

Danielle Robitaille MD FRCPC

\begin{abstract}
"La transfusion est comme le mariage: on ne l'entreprend jamais avec légèreté, sans raisons et au hasard, et plus souvent qu'il ne faut "
\end{abstract}

R.W. Beal ${ }^{1}$

Avant l'apparition du syndrome d'immuno-déficience acquise (SIDA), on considérait la transfusion du sang comme un acte plutôt banal. Il en est résulté une augmentation constante de l'utilisation du sang et de ses dérivés au point où l'offre suffisait à peine à la demande. Le SIDA est venu bouleverser dramatiquement le concept de linnocuité du sang, tant chez le médecin que chez le patient. Entre 1980 et 1985, la stratégie transfusionnelle a subi des changements majeurs. ${ }^{2}$ L'abondance de la littérature récente reflète bien linquiétude provoquée par les complications associées aux transfusions de sang. ${ }^{3-6}$

Cette mise à jour a pour objectif: 1) de revoir brièvement les complications infectieuses associées aux transfusions; 2) de réexaminer les indications des produits sanguins homologues (PSH); 3) de discuter des stratégies alternatives offertes pour diminuer ou éviter les transfusions de PSH. Une attention particulière sera accordée au problème canadien.

\section{Les complications infectieuses de la transfusion}

Les complications provoquées par le sang homologue ont déjà donné lieu à de nombreuses publications ${ }^{3,4}$ et apparaissent au Tableau I. Le risque infectieux des transfusions s'est atténué ces dernières années grâce aux politiques de dépistage du donneur (Tableau II) introduites par le service de transfusion de la Société Canadienne de la Croix-Rouge.?

En général, la contamination bactérienne ne présente pas de problème, excepté pour les préparations de plaquettes qui sont stockées à la température de la pièce ou en présence du Yersinia enterolitica pour lequel la température de $4^{\circ} \mathrm{C}$ n'a pas la même efficacité bactériostatique que pour les autres bactéries. Au Canada, les parasites ne causent pas de problème sérieux. Les infections les plus fréquentes associées aux transfusions de produits sanguins homologues demeurent l'hépatite post-transfusionnelle (HPT): le virus de l'hépatite A, le cytomégalovirus et le virus d'Epstein-Barr transmettent rarement l'HPT.

Aux E.U.A., la fréquence de l'HPT transmise par le virus de l'hépatite B est évaluée à 1 sur 50,000 receveurs ou 1 sur 200,000 unités transfusées. ${ }^{8}$ Quatre-vingt-dix pour cent des cas (dont la majorité est asymptomatique) évoluent spontanément vers la guérison, cinq à dix pour cent vers la chronicité (dont la moitié deviendront des porteurs asymptomatiques) ou vers une hépatite fulminante (avec un taux de mortalité plus élevé que $50 \%$ ). Les statistiques canadiennes sont identiques. Au cours des trois dernières années, le centre de transfusion de Montréal n'a rapporté qu'un seul cas d'hépatite $B$ posttransfusionnelle (communication de Gilles Delage du centre de Montréal de transfusion de la Société Canadienne de la Croix-Rouge). Si on assume, que seulement $25 \%$ des infections sont symptomatiques, on obtient un taux d'infection identique à celui des US.

Le virus de l'hépatite $C(\mathrm{HCV})$ est l'agent responsable de la plupart des HPT non A-non B, mais pas de toutes. Comme pour l'hépatite $B$, lincidence d'HPT associée au HCV varie selon la population étudiée. Au Canada, le taux d'infection est le même qu'aux USA (communication personnelle, Gilles Delage), c.-à-d. environ 1 sur 3,000 produits sanguins transfusés. ${ }^{9}$ L'hépatite $C$ posttransfusionnelle se manifeste initialement de façon bénigne mais $50 \%$ des patients évoluent vers la chronicité (état du porteur persistant) et de 10 à $20 \%$ de ceux-ci développent une cirrhose.

En 1992, Crosby rapportait qu'au Canada, depuis l'implantation des mesures de dépistage en 1985, seulement deux conversions probables au VIH (sur 15 millions d'unités de produits sanguins administrés) ont été associées aux transfusions. ${ }^{3}$ Les mesures usuelles de dépistage consistent à détecter les anticorps du VIH. En moyenne, ces anticorps sont négatifs pendant huit semaines après l'infection mais la séro-conversion peut survenir aussi tardivement qu'après 42 mois. De là, la possibilité que quelques unités contaminées puissent échapper à la détection systématique des anticorps du VIH. ${ }^{10}$ Toutefois, grâce à la sélection actuelle des donneurs et aux tests sanguins, le risque de transmission du VIH par transfusion sanguine se situe entre $1 / 40,000$ et $1 / 1,000,000$. $^{11}$

Le HTLV-1 et le HTLV-2 sont associés à la leucémie, au lymphome, à la paraparésie spastique tropicale; une myélopathie est associée au HTLV-1. En Amérique du Nord, la transmission du HTLV-1 est rare et les risques associés sont difficiles à évaluer.

Tout porte à croire qu'environ trois receveurs sur 10000 contractent une maladie virale grave ou fatale par transfusion sanguine. ${ }^{8}$ Selon la Croix-Rouge canadienne, 
TABLEAU I Classification des réactions transfusionnelles, 3.5

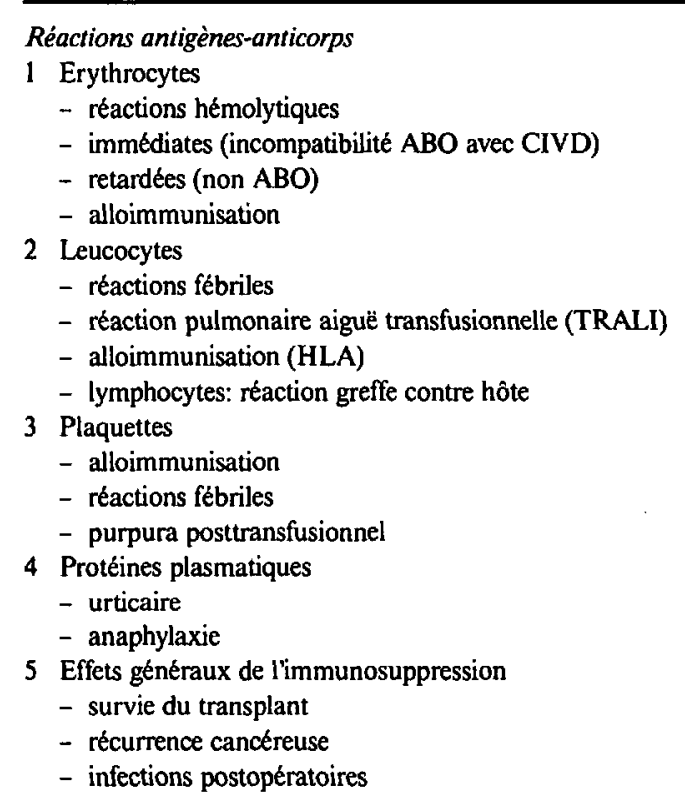

Réactions non immunologiques

1 Transmissions des maladies

- hépatite A, B, nAnB/C

- HIV 1, HIV 2, HTLV 1, HTLV 2

- cytomégalovirus, Virus d'Epstein-Barr

- syphilis, malaria, babeosiose, trypanosomiase

- contamination bactérienne

2 Embolie

- aérienne

- microembolies

3 Surcharge

- liquidienne

- déséquilibre électrolytique

- surcharge ferrique

- excès de citrate

4 Anomalies de l'hémostase

- thrombocytopenie

- déficits en facteurs de coagulation

5 Hypothermie

la transfusion de sang et de ses dérivés s'accompagnent de risques aussi difficiles à prédire qu'à prévenir. Le médecin ne doit prescrire une transfusion que lorsqu'elle est essentielle ou lorsqu'aucune autre forme de traitement ne peut lui être substituée.

\section{Les indications des produits sanguins homologues}

Chaque unité de sang complet $(450 \mathrm{ml}$ dans $63 \mathrm{ml}$ d'anticoagulant) est fractionnée de quatre à six heures après son prélèvement. Le fractionnement permet de stocker sous des conditions optimales chacun des composants et par la suite d'administrer la fraction requise selon le besoin du patient. On peut ainsi répartir le sang d'un seul donneur entre plusieurs receveurs. De tous les dérivés du sang distribués par la Croix-Rouge (Tableau III), les
TABLEAU II Sélections des donneurs et tri des dons au Canada

1 Identification formelle du nouveau donneur.

2 Dépistage méticuleux du donneur par la personnel de la clinique.

3 Possibilité de l'auto-exclusion confidentielle du donneur après don du sang.

4 Test du sang recueilli

- ABO, Rh et anticorps érythrocytaires rares

- antigène de surface de l'hépatite B

- anticorps anti HIV 1 et HIV 2

- virus humain lymphotrope des cellules (HTLV)

- virus de lhépatite $\mathrm{C}$

- treponema pallidum (syphilis)

5 Exclusion du sang présentant une épreuve de dépistage positif.

6 Epreuves supplémentaires sur le sang positif.

7 Notification écrite de tous les donneurs positifs.

8 Exclusion temporaire, indéfinie ou permanente des donneurs.

TABLEAU III Produits sanguins distribués par la Croix-Rouge Canadienne

Composants cellulaires

1 Erythrocytes

2 Erythrocytes sans leucocytes

3 Erythrocytes déglycérolisés

4 Plaquettes de donneurs choisis au hasard

5 Leucocytaphérèse

Plasma et compasants plasmatiques

1 Plasma

2 Plasma frais congelé

3 Cryoprécipité FAH (facteur antihémophilique)

Fractions plasmatiques

1 Solutions de remplissage vasculaire

2 Concentré de facteurs de coagulation

- facteur VIII

- facteur porcin VIII:C

- complexe de facteur (humain) IX traité à la vapeur

- facteur de coagulation (humain) IX de haute pureté

- complexe coagulant anti-inhibiteur traité à la vapeur: FEIBA

- concentré de facteur VII*

- produits spéciaux de coagulation $\dagger$

- fibrinogène: concentré At-III; Humate P; concentré de facteur XI; concentré de facteur XIII; concentré de protéine C

3 Préparations d'immunoglobuline

- immunoglobuline sérique; intramusculaire

- immunoglobuline varicelle-zoster

- immunoglobuline de l'hépatite B (humaine)

- immunoglobuline intraveineuse

- immunoglobuline Rho (D)*

- hyperimmunoglobuline CMV

- produit spécial†: inhibiteur de l'estérase Cl

*Libération d'urgence requise.

†Libération d'urgence et l'approbation de l'Agence Canadienne du Sang requises.

globules rouges, le plasma frais congelé (PFC) et les plaquettes sont les seuls qu'administrent ordinairement les anesthésistes et qui constituent un risque potentiel d'in- 
fection. Les indications de ces produits du sang complet seront revues sur la base des conférence de consensus convoquées par l'Office of Medical Applications du National Institute of Health (USA). ${ }^{11-13}$

\section{Indications de la transfusion des hématies (concentré érythrocytaire)}

Les concentrés érythrocytaires sont préparés en soutirant après centrifugation le plasma qui surnage le sang complet. Un sac de culot contient $200 \mathrm{ml}$ de globules rouges avec de l'anticoagulant CPDA-1 ou de l'anticoagulant CP2D et $100 \mathrm{ml}$ d'additif AS-3 (Nutricel(i⿶)), et 90 ou $60 \mathrm{ml}$ de plasma. La survie de stockage est de 35 jours à $1^{\circ}-6^{\circ} \mathrm{C}$, mais les culots contenant de l'AS-3 ont un potentiel de survie de 42 jours. On peut ajouter du soluté physiologique isotonique à ces préparations pour augmenter le débit des érythrocytes. Les concentrés érythrocytaires doivent être administrés à travers un filtre de $170 \mu$.

La Conférence reconnaît qu'aucune évidence ne supporte l'utilisation d'un seul critère transfusionnel, tel que un taux dhémoglobine $<100 \mathrm{~g} \cdot \mathrm{L}^{-1}$. " La décision de transfuser un patient doit tenir compte de la durée de l'anémie, du volume circulant, de la complexité de l'intervention, de la probabilité de pertes sanguines importantes et de la présence de conditions co-existantes comme une altération de la fonction respiratoire, une insuffisance du débit cardiaque, une ischémie myocardique ou une affection cérébrovasculaire ou vasculaire périphérique ". "Comme l'énonce la Conférence, les indications de la transfusion d'érythrocytes sont encore mal définies et des recherches devraient permettre de les déterminer. Alors " qu'aucune mesure unique ne remplace le bon jugement clinique comme base de décision au regard des transfusions périopératoires ", est-il possible de perfectionner nos critères de transfusion d'érythrocytes?

L'érythrocyte a pour fonction de transporter et de libérer aux cellules l'oxygène alvéolaire. Lors d'une perte sanguine aiguë, on admet généralement que la restauration de la volémie est plus importante que la composition du liquide de remplacement. Ainsi, les érythrocytes ne devraient pas être administrés pour remplacer le volume perdu, mais seulement pour traiter l'anémie et la baisse de capacité de transport de l'oxygène du sang associée à l'hémorragie grave. La transfusion de concentré érythrocytaire est alors utilisée pour augmenter l'apport en oxygène aux tissus. L'augmentation anormale de lindex cardiaque et de la consommation d'oxygène sont aussi des facteurs déterminants de survie lors du choc septique ou hémorragique. ${ }^{14}$

Pendant l'hémodilution normovolémique (l'anémie sans hypovolémie), la viscosité sanguine diminue et la $\mathrm{DO}_{2}$ demeure relativement constante entre des valeurs d'hématocrite de 28 et $45 \% .^{5}$ Si l'hématocrite s'abaisse encore plus, la $\mathrm{V}_{2}$ se maintient à des valeurs situées près de la limite de la normale, soit par augmentation du débit cardiaque, soit par augmentation du rapport d'extraction systémique de l'oxygène $\left(\mathrm{REO}_{2}\right)$. L'augmentation du $\mathrm{REO}_{2}$ est en quelque sorte limitée par une $\mathrm{EO}_{2}$ déjà élevée dans la circulation cérébrale et coronaire ( $55-70 \%$ vs $25 \%$ pour le $\mathrm{REO}_{2}$ systémique). Toutefois chez le babouin, on a noté pendant l'hémodilution normovolémique progressive, que le $\mathrm{REO}_{2}$ systémique doit dépasser $50 \%$ pour que le myocarde passe de la consommation de lactate à sa production. ${ }^{15}$ Les malades âgés ou coronariens peuvent être incapables d'augmenter leur débit cardiaque pour compenser pour l'anémie. ${ }^{5}$ Quand les mécanismes compensateurs font défault, la $\mathrm{VO}_{2}$ diminue et les tissus utilisent le métabolisme anaérobique pour survivre.

Dans leur révision méticuleuse de la littérature d'après 1968, Welch et al. ont noté chez le patient bien portant une tolérance remarquable pour les concentrations basses en hémoglobine (entre 50 et $70 \mathrm{~g} \cdot \mathrm{L}^{-1}$ ); ils suggèrent que le clinicien accepte pour la plupart des anémiques stables un taux $>70 \mathrm{~g} \cdot \mathrm{L}^{-1} \cdot{ }^{16}$ Les conclusions de la conférence de consensus sur les transfusions périopératoires d'érythrocytes ne sont pas aussi explicites mais parviennent aux mêmes recommandations. Le comité médical des transfusions de l'ASA énonce qu'un taux d'hémoglobine de 60 à $80 \mathrm{~g} \cdot \mathrm{L}^{-1}$ ne présente pas de danger pour le patient sans affections cardio-pulmonaires. ${ }^{17}$ Cependant, il faut reconnaître que, pour la $\mathrm{DO}_{2}$, la marge de sécurité diminue avec la concentration en hémoglobine et que les patients atteints d'affections cardiovasculaires sérieuses peuvent ne pas tolérer l'hémodilution aux concentrations d'hémoglobine plus basses que 80 à $100 \mathrm{~g} \cdot \mathrm{L}^{-1} .{ }^{17,18}$ Toutefois, les effets des transfusions administrées pour corriger l'anémie sur le métabolisme myocardique en oxygène ne se limitent pas à la correction de la baisse de l'apport en oxygène; le clinicien doit aussi tenir compte de l'aggravation possible de l'ischémie par augmentation du volume sanguin, de la postcharge et de la viscosité sanguine. ${ }^{16}$ L'hémodilution jusqu'à un hématocrite de 15\% est bien tolérée chez l'humain sous anesthésie après chirurgie de dérivation myocardique sans évidence électrocardiographique ou métabolique d ischémie. ${ }^{19}$

Le taux d'hémoglobine n'est pas un indicateur absolu des transfusions de concentrés érythrocytaires. La perte sanguine peropératoire demeure toujours un critère spécifique et valide. Lors de l'étude d'une cohorte de 125 patients qui refusaient la transfusion pour des motifs religieux, aucun des patients dont le taux d'hémoglobine était supérieur à $80 \mathrm{~g} \cdot \mathrm{L}^{-1}$ et les pertes sanguines peropératoire inférieures à $500 \mathrm{ml}$ n'est décédé. La mortalité est passée de $8 \%$ à $43 \%$ lorsque les pertes ont augmenté 
de $500 \mathrm{ml}$ à plus de $2000 \mathrm{ml}$ malgré le maintien d'une volémie adéquate. ${ }^{20}$

Comme le contenu en oxygène du sang n'est pas le seul déterminant de la $\mathrm{DO}_{2}$ et de la $\dot{\mathrm{VO}}_{2}$, l'efficacité de la transfusion des concentrés érythrocytaires doit être monitorée. Il est intéressant de noter que, chez le chien, l'hémodilution modérée jusqu'à un hématocrite de 20 ou $30 \%$ est associée à une amélioration de la capacité d'extraction systémique de l'O $\mathrm{O}_{2}$ (une $\mathrm{DO}_{2}$ critique plus basse et un $\mathrm{REO}_{2}$ critique plus élevé pendant l'hémorragie), comparativement à l'hémorragie abaissant l'hématocrite à $40 \% .{ }^{29} \mathrm{La}$ réponse de la $\dot{\mathrm{VO}}_{2}$ à l'administration de concentrés érythrocytaires constitue un bon critère de justification. Linconvénient pratique de cette recommandation vient du fait que la mesure de la $\dot{\mathrm{VO}}_{2}$ exige un monitorage hémodynamique effractif. Cependant, l'augmentation de la lactasémie indique avec précocité l'insuffisance de la perfusion et met en évidence la dette en oxygène. Avec les analyseurs de gaz sanguins automatisés, la lactasémie est mesurable instantanément et procure un témoignage non effractif du métabolisme anaérobique. Une augmentation subite de la lactasémie est observée quand la $\mathrm{DO}_{2}$ diminue sous la valeur critique. ${ }^{21}$ Ainsi, au moins dans un sous-groupe de patients, la lactasémie peut devenir un indicateur utile pour déterminer la pertinence des transfusions de concentré érythrocytaire. ${ }^{22}$

Une autre fonction moins connue des globules rouges consiste à augmenter l'interaction interplaquettaire et à faciliter l'interaction des plaquettes avec la membrane basale de l'endothélium. La transfusion d'érythrocytes normalise le temps de saignement des anémiques thrombocytopéniques malgré une thrombocytopénie persistante. ${ }^{23}$ De la même façon, les hématies contrôlent la tendance hémorragique de l'anémique et abrègent son temps de saignement. ${ }^{24}$ Toutefois, un taux dhémoglobine acceptable pour le maintien de la $\mathrm{DO}_{2}$ peut être insuffisant pour procurer une hémostase optimale. Ceci peut aider à expliquer pourquoi, après CEC, l'effet hémostatique d'une seule unité de sang frais est au moins égale, sinon supérieure à dix unités de plaquettes. ${ }^{25}$

\section{Indications de la transfusion de plaquettes $7,13,17$}

Dans le contexte de l'anesthésie et de la chirurgie, les concentrés plaquettaires sont les deuxièmes produits sanguins les plus utilisés après les érythrocytes. Les plaquettes sont concentrées dans $30-50 \mathrm{ml}$ de plasma et le produit final contient un petit nombre de leucocytes et d'hématies (jusquà $0.4 \mathrm{ml}$ par unité). Le stockage à la température de la pièce $\left(20^{\circ}-24^{\circ} \mathrm{C}\right)$ préserve la fonction et une agitation lente et continuelle prévient la formation d'aggrégats. On limite le stockage à deux jours pour éviter la croissance bactérienne. Chez l'adulte normal, une unité de concentré plaquettaire augmente le décompte par 5-10 $\times 10^{9} \cdot \mathrm{L}^{-1}$ une heure après son administration. Ainsi, la dose usuelle est de six à huit unités, ce qui expose le receveur à autant de donneurs. Les unités de plaquettes peuvent être mélangées dans un seul sac avant l'administration qui doit se faire en-deçà de six heures. L'utilisation d'un filtre de $170 \mu \mathrm{m}$ est recommandée. Il est accepté d'administrer des plaquettes incompatibles $A B O$. Même avec des plaquettes compatibles $\mathrm{ABO}$, une immunisation $\mathrm{Rh}$ chez les femmes en âge de porter des enfants est toujours possible. Dans certaines circonstances, on peut être forcé d'utiliser des plaquettes de donneurs uniques au hasard ou typés pour le HLA.

Les thrombocytopéniques graves peuvent bénéficier de transfusions de plaquettes pour la prévention de l'hémorragie. En milieu hospitalier, on considére généralement la valeur empirique de $20 \times 10^{9} \cdot \mathrm{L}^{-1}$ plaquettes comme adéquate. Les thrombocytopéniques chroniques n'ont généralement pas besoin de transfusion systématique de plaquettes mais peuvent bénéficier de l'administration prophylactique de plaquettes avant la chirurgie ou d'autres manoeuvres effractives. On suggère une consultation en hématologie pour déterminer individuellement la numération optimale pour chaque patient. D'autres mesures comme l'administration $\dot{i}$ d'immunoglobines peuvent normaliser le décompte dans le purpura thrombocytopénique idiopathique.

En règle générale, les produits sanguins administrés pour l'hémostase, comme les concentrés de plaquettes et le PFC, ne devraient jamais l'être en absence de saignement sur la foi des seuls tests de laboratoire. Les thrombocytopéniques ou tous les patients dont la fonction plaquettaire est anormale et qui saignent, ne devraient en recevoir que si on croit que la déficience plaquettaire cause le saignement ou y contribue. ${ }^{33}$ Il est possible d'obtenir très rapidement une numération plaquettaire raisonnablement précise avec un compteur automatique. En absence de dysfonction plaquettaire, on ne peut tenir responsable d'un saignement actif un décompte de $50 \times$ $10^{9} \cdot \mathrm{L}^{-1}$ ou plus. La fonction plaquettaire est beaucoup plus difficile à évaluer et jusqu'à maintenant, on n'a pas identifié la méthode idéale de le faire. L'apparence de la plaie chirurgicale, le temps de saignement avec témoin, le thromboélastogramme, et l'analyse avec le Sonoclot Signature ${ }^{\circledR}$ peuvent fournir une appréciation valable de la fonction plaquettaire.

La transfusion massive est définie ordinairement par l'administration rapide de l'équivalent du volume sanguin dans une intervalle de quelques heures. Elle peut conduire à une coagulopathie caractérisée par du saignement micro-vasculaire (suintement typique généralisé) après 15-20 unités de concentré érythrocytaire chez un adulte jusque là « bien portant ${ }^{26,27} \mathrm{Par}$ ordre de fréquence, 
les coagulopathies résultent: 1) de la perte de plaquettes, et très rarement, des facteurs labile V et VIII; 2) de la coagulation intravasculaire disséminée (CIVD) associée au choc; et 3) de réactions transfusionnelles hémolytiques. ${ }^{13} \mathrm{La}$ libération par la rate et la moelle osseuse de plaquettes aide à prévenir la thrombocytopénie dilutionnelle mais en présence de saignement microvasculaire, un décompte plaquettaire à $50-100 \times 10^{9} \cdot \mathrm{L}^{-1}$ constitue une indication pour la transfusion de plaquettes. ${ }^{26,27}$

Les indications de transfuser des plaquettes après la CEC ne diffèrent pas et on n'est jamais justifié de les administrer prophylactiquement aux patients qui subissent une intervention cardiaque à coeur ouvert.

Quand le saignement ne tarit pas après des transfusions adéquates de plaquettes, le prochain choix logique consiste à administrer du plasma frais congele. ${ }^{28}$

\section{Les indications du $P F C^{7,12,17}$}

Après la séparation des plaquettes, ce qui reste du plasma est congelé rapidement pour prévenir l'activation des facteurs de coagulation thermosensibles (" labiles ") V et VIII. L'unité de PFC, de $190-260 \mathrm{ml}$ en volume, est stockée à la température de $-18^{\circ} \mathrm{C}$. Le $\mathrm{PFC}$ a peu d'indications spécifiques. Il n'est pas justifié d'utiliser le PFC pour le remplissage vasculaire et les besoins de la nutrition. On n'a jamais prouvé que l'administration de PFC avait sa place dans le traitement des hemorragies massives. Le PFC contient tous les facteurs plasmatiques de coagulation à un niveau d'activité à peu près normal. Il est indiqué dans le traitement de déficits en facteurs quand la thérapie spécifique n'est pas disponible ou inappropriée. Dans ce contexte, la recommandation de la meilleure thérapie viendra de la consultation hématologique.

Les déficits fonctionnels induits par les anticoagulants oraux peuvent être renversées par la vitamine $\mathrm{K}$. Comme la vitamine $\mathrm{K}$ sous-cutanée met de 6 à 24 heures pour neutraliser les effets des anticoagulants, on utilise le plasma frais congelé pour une hémostase rapide en cas d'un saignement actif ou d'une chirurgie urgente.

Le plasma frais congelé peut être utilisé chez les transfusés massifs qui saignent activement quand un déficit des facteurs de la coagulation est reconnu comme la cause du saignement. Cependant, dans cette situation, les cliniciens doivent considérer la thrombocytopénie comme la cause la plus fréquente de l'hémorragie. La conférence de consensus admet que dans certaines circonstances, le PFC peut avoir une valeur thérapeutique (ex. déficiences multiples en protéines de coagulation lors d'une hémorragie incontrôlable) mais les preuves de son efficacité sont vagues ou non reconnues. L'administration prophylactique de PFC chez le polytransfusé n'a pas fait ses preuves non plus.

Finalement, le PFC peut servir comme source d'an- tithrombine III, pour le traitment des immunodéficiences spécifiques et pour le traitement du purpura thrombocytopénique.

Lors d'un saignement actif, lorsque le PFC est indiqué, l'administration rapide de grands volumes (quatre à huit unités) est nécessaire pour produire une augmentation notable de la concentration des facteurs de coagulation. ${ }^{29}$ En absence de saignement actif, deux unités de PFC suffisent pour renverser l'effet de la warfarine ou de la coumadine en cas de besoin. Cependant, cet effet n'est que transitoire (six à huit heures) et une récurrence de la coagulopathie est à craindre si on n'a pas administré de vitamine $\mathbf{K}$.

\section{Comment éviter les produits sanguins homologues}

Plusieurs stratégies sont recommandées dans le but de diminuer et même de supprimer les transfusions de PSH (Tableau IV). Certaines sont inoffensives mais d'autres comportent des risques qui doivent être pesés chaque fois qu'on administre un PSH.

\section{Stratégies préopératoires}

Les anti-inflammatoires non stéroïdiens (AINS), ${ }^{30}$ l'acide acétylsalicylique (ASA), ${ }^{31}$ et possiblement quelques inhibiteurs calciques sont associés au saignement periopératoire; avant une chirurgie réglée, ils devraient être discontinués ou du moins remplacés lorsque possible par des produits à demi-vie plus courte.

Etant donné les risques entrainés par l'administration des PSH, on a suggéré d'obtenir un consentement éclairé avant les transfusions, ${ }^{37}$ mais on ne s'entend pas sur une forme du consentement verbal ou écrit. ${ }^{17}$ L'anesthésiste doit toutefois toujours inscrire au dossier d'anesthésie ses indications pour l'administration de PSH. ${ }^{17}$ En Californie, le Paul Gann Blood Safety Act rend obligatoire la notification du risque transfusionel et de ses alternatives. Cette loi semble avoir polarisé l'attention sur les méthodes de conservation du sang et a provoqué une baisse du nombre de transfusions de PSH en chirurgie cardiaque. ${ }^{38}$

Certaines stratégies peuvent atténuer les pertes sanguines peropératoires.

On connaît déjà plusieurs techniques qui permettent de diminuer les pertes sanguines pendant la chirurgie. Elles comprennent lutilisation du garrot, l'infiltration d'anesthésiques locaux adrénalinés, le drainage veineux du site opératoire, l'hypotension contrôlée mais surtout l'hémostase méticuleuse pratiquée par le chirurgien. On a aussi montré qu'en chirurgie cardiaque le contrôle du stress favorisait l'hémostase, mais son influence sur les pertes sanguines et les besoins transfusionnels n'est pas prouvée. ${ }^{39}$

Le maintien de la normothermie constitue pour l'hémostase un élément important quoique souvent 
TABLEAU IV Stratégies de réduction des besoins en produits sanguins homologues à la période périopératoire

1 Avant la chirurgie

- éviter les phlébotomies préopératoires inutiles

- éviter ou cesser les drogues quj affectent la coagulation: ex. ASA, AINS

- administrer de l'érythropö̈́tine recombinante pour augmenter l'Hb

- recourir à la transfusion autologue différée

- consentement éclairé

2 Mesures de réduction de la perte sanguine peropératoire

- technique chirurgicale méticuleuse

- maintien de la normothermie

- techniques accessoires:

- garot

- infiltration locale avec de l'adrénaline

- drainage veineux adéquat de la plaie chirurgicale

- hypotension controblée

- agents pharmacologiques

- desmopressine (DDAVP)

- antifibrinolytiques naturels et synthétiques

3 Mesures permettant de diminuer le risque d'anémie

- réduction de la consommation en $\mathrm{O}_{2}$

- anesthésie, sédation

- ventilation mecanique

- prévention du frissonnement

- optimisation de la fonction de l'hémoglobine circulante

- augmentation du transport de $\mathrm{l}^{\prime} \mathrm{O}_{2}$ : supplément d' $\mathrm{O}_{2}$ pour augmenter la $\mathrm{PaO}_{2}$

4 Les alternatives aux érythrocytes homologues (de donneurs au hasard)

- attention et éducation

- tolérance des concentrations basses en hémoglobine

- transfusions autologues

- prélèvement préopératoires

- transfusions peropératoires différées: hémodilution normovolémique

- retransfusion per- et postopératoires du sang versé

- dons dirigés

- substituts sanguins

oublié. L'hypothermie provoque une dysfonction plaquettaire réversible; après la $\mathrm{CEC}$, le réchauffement rétablit la fonction plaquettaire, abrège le temps de saignement et diminue la perte sanguine. ${ }^{40} \mathrm{On}$ conseille de réchauffer le patient hypothermique avant de lui administrer des $\mathrm{PSH}$, que ce soit après la CEC ou un traumatisme. ${ }^{40}$ De plus, l'hypothermie inhibe fortement les réactions enzymatiques de la cascade de la coagulation; comme les épreuves de coagulation sont réalisées à $37^{\circ} \mathrm{C}$, on peut facilement oublier la contribution de l'hypothermie à la coagulopathie. ${ }^{40}$

Le traitement pharmacologique de l'hémorragie surtout après la CEC, attire de plus en plus attention. ${ }^{42,43}$ Cette therrapie a plusieurs avantages: on peut l'appliquer instantanément, elle est facile à gérer, elle ne nécessite pas d'équipements coûteux, et elle peut être utilisée de façon préventive. La desmopressine (DDAVP), un analogue de la vasopressine, l'acide epsilon-aminocaprö̈que (EACA) et l'acide tranexamique (TA), tous deux des antifibrinolytiques synthétiques, et l'aprotinine (Apt), un antifibrinolytique dérivé du poumon de boeuf ont été utilisés soit pour diminuer, soit prévenir le saignement excessif associé à la chirurgie cardiaque et à d'autres chirurgies lourdes.

En 1986, Salzman et al. ont montré au cours d'une étude prospective, à double insu, contrôlée et randomisée, que le DDAVP diminuait la perte sanguine en chirurgie cardiaque. ${ }^{44}$ Plus tard, avec le même protocole, d'autres études réalisées par des auteurs différents n'ont pu reproduire ces résultats. On explique les résultats de Salzman par le fait que les pertes sanguines au cours de son étude étaient extrèmement élevées et que ses résultats ne pouvaient être extrapolés à d'autres centres où les pertes étaient beaucoup moins considérables. Bien que la thromboélastographie réussisse à identifier un sous-groupe de patients pour lesquels le DDAVP pourrait être utile, ${ }^{45}$ son efficacité demeure controversée. ${ }^{46,47}$ De la même façon, on ne s'entend pas sur l'efficacité du DDAVP pendant la fusion vertébrale chez le scoliotique. ${ }^{48,49} \mathrm{De}$ plus, le DDAVP pourrait provoquer des thromboses et ne devrait être utilisée qu'avec prudence chez le sujet âgé et chez les athéromateux. ${ }^{50,51}$

L'administration prophylactique de l'EACA et du TA a surtout été limitée à la chirurgie cardiaque et à la chirurgie mineure de l'hémophile. Des données rétrospectives recueillies chez 411 patients du Toronto Hospital montrent que le TA à la dose de $10 \mathrm{~g}$ diminue le saignement post-CEC des 24 heures initiales, prévient le saignement excessif ( $>750 \mathrm{ml}$ en six heures) et réduit le pourcentage des patients qui reçoivent des PSH. ${ }^{52}$ D'autres données fournies par la même institution montrent que le TA, l'EACA et la perfusion normothermique sont tous aussi efficaces pour diminuer l'hémorragie postopératoire et conserver les plaquettes. ${ }^{53}$ Sans données supplémentaires, on ne peut présentement déterminer en chirurgie cardiaque la posologie optimale et l'efficacité de ces drogues. L'EACA et le TA ont la même efficacité pour traiter la fibrinolyse et contrôler le saignement associés à la transplantation hépatique, bien qu'on ne puisse recommander l'usage universel de ces produit à cause du danger de thrombose. ${ }^{54}$

L'aprotinine est un polypeptide formé des résidus de 58 acides aminés qui inhibe un vaste spectre de protéases. En plus de l'activité antiplasmine (antifibrinolytique) qu'elle partage avec l'EACA et le TA, l'aprotinine inhibe l'activation de la kallicréine et la cascade de la coagulation secondaire à la libération de l'activateur du plasminogène tissulaire. Cette double action est, semble-t-il, responsable pour son efficacité généralement reconnue en chirurgie cardiaque. ${ }^{42}$ L'aprotinine a été aussi utilisée avec succès 
dans l'hématome rétro-placentaire compliqué d'une coagulation intravasculaire disséminée, ${ }^{55}$ pour la prévention de la récurrence du saignement après l'hémorragie sousarachnoïdienne ${ }^{56}$ et pour le contrôle du saignement orthopédique (communication personnelle du $\mathrm{Dr}$ John Murkin) et vasculaire chirurgical. ${ }^{57}$ Dans plusieurs centres, on administre systématiquement comme mesure prophylactique de l'aprotinine à haute dose (dose de charge deux millions de KIU, suivie d'une perfusion de 500000 $\mathrm{KIU} \cdot \mathrm{h}^{-1}$ ); administrée de cette façon, l'aprotinine diminue le saignement périopératoire et les besoins en PSH pendant la transplantation hépatique ${ }^{58,59}$ et la chirurgie cardiaque (on ajoute deux millions KIU à l'amorce de la CEC).$^{60}$ L'administration d'aprotinine peut provoquer des réponses allergiques mineures ou de l'anaphylaxie, spécialement si on la répète mais le risque de ces complications est minime $(<1 \%){ }^{61}$ Malgré les craintes que de fortes doses d'aprotinine puissent augmenter les complications thrombotiques, le bilan de l'aprotinine est jusqu'à maintenant impressionnant sous l'aspect de la sécurite. 62,63

\section{Les mesures qui diminuent lincidence de l'anémie}

Ces mesures ont bien connues des anesthésistes et il n'est pas nécessaire d'en faire la description ici. Elles permettent d'atténuer les conséquences physiologiques de l'anémie pendant qu'on confirme la nécessité de recourir aux transfusions.

\section{Les alternatives au sang homologue à la période périopératoire}

Malgré tous nos efforts de prévention, la transfusion de concentré érythrocytaire peut devenir nécessaire. Encore là, nous disposons de stratégies d'économie du sang homologue. D'abord, ceux qui prescrivent les transfusions ne devraient le faire qu'après mûre réflexion et devraient éviter de réagir automatiquement comme s'il s'agissait d'un stimulus physiopathologique. L'attention portée à une batterie de critères arbitraires plutôt qu'aux besoins du patient explique la grande variabilité de la pratique transfusionnelle en chirurgie cardiovasculaire. ${ }^{64}$ " Les patients savent que cette pratique est inacceptable; il nous faut aussi le reconnaitre. Le sang et ses dérivés ne doivent être administrés que lorsque lindication en est certaine $"{ }^{65}$ Il s'ensuit donc que ceux qui prescrivent des transfusions doivent en connaître parfaitement les indications et les risques.

La tolérance de l'organisme aux basses concentrations d'hémoglobine a été étudiée et constitue un premier pas vers la diminution des transfusions de PSH. Bien que les limites de l'hémodilution soient encore à définir, les transfusions guidées par des indications cliniques valides et une baisse en de l'hématocrite sous le niveau de $25 \%$, ont fait diminuer les besoins en globules rouges chez des patients soumis à une revascularisation myocardique; on a constaté chez ces patients la même tolérance à l'exercice et l'absence de conséquences nocives, lorqu'on les comparait à d'autres dont l'hématocrite était maintenu à un niveau plus élevé que $32 \% .{ }^{66}$

Les prélèvements de sang autologue demeurent sousutilisés mais devraient être considérés avant toutes les interventions pour lesquelles on a l'habitude de faire des épreuves de compatibilité. Les dons de sang autologue diminuent les besoins en PSH en partie parce que les médecins tolèrent des concentrations plus basses d'hémoglobine chez le donneur autologue. ${ }^{67}$ Le sang autologue est immunologiquement identique au sang du receveur et offre pour la transfusion la plus grande sécurité qui soit. On a donc tendance à transfuser le sang autologue sans retenue mais afin d'éviter la surcharge et lhyperviscosité on ne le devrait le faire qu'en cas d'anémie. Le risque d'administrer un sang incompatible en raison d'une erreur didentification est toujours présent. Un programme de pré-dons est en place aux cliniques permanentes de transfusion de la Croix-Rouge. ${ }^{7}$ On peut fournir une unité de sang par semaine jusqu'à un maximum de quatre unités. Tous les patients sont acceptables, mais ceux qui sont à haut risque comme les malades cardiaques graves doivent s'adresser à des centres spécialisés. Les sacs de sang autologues sont identifiés avec une étiquette verte et doivent être vérifiés comme s'ils contenaient des PSH. Présentement, ce sang n'est pas transfusé à d'autres receveurs.

Sans dons préalables, on peut utiliser le sang autologue sous d'autres formes. L'hémodilution normovolémique (HN) est efficace, sans danger et facile à réaliser. ${ }^{68}$ Sous des conditions stériles, le sang prélevé par une grosse veine périphérique ou une artère est recueilli dans des sacs contenant de l'anticoagulant. Le volume de sang à retirer dépend du volume sanguin estimé du patient (VSE), de l'hématocrite initial (Hi) et de l'hématocrite final (Hf) et se calcule comme suit:

Volume à prélever $=\mathrm{VSE} \times \frac{\mathrm{Hi}-\mathrm{Hf}}{\mathrm{Hm}}$

où $\mathrm{Hm}$ est la moyenne de $\mathrm{Hi}$ et $\mathrm{Hf}$, ce qui permet de faire la correction pour la dilution en cours. ${ }^{69}$

Une normovolémie stricte doit être maintenue. On peut remplacer soit avec des colloïdes, soit avec des critalloïdes selon la condition du patient et sa capacité de tolérer des échanges hydroélectrolytriques importants. Chaque unité recueillie est étiquettée et gardée à la température de la pièce pendant un maximum de six heures pour conserver la fonction plaquettaire. Le sang est retourné à la circulation au moment approprié, de préférence une fois l'hémorragie contrôlée. La principale contre- 
indication de l'HN est l'anémie, mais l'ischémie ou l'instabilité hémodynamique limitent la quantité de sang qui peut être prélevée sans danger. ${ }^{70}$

La récupération peropératoire des hématies par aspiration et lavage automatisés s'est avérée utile pendant la chirurgie cardiaque, vasculaire, orthopédique et traumatologique. ${ }^{17}$ Les complications potentielles sont nombreuses dont la coagulopathie lorsque de grands volumes de cellules lavées sont reperfusés. Cependant, les désavantages majeurs de cette technique sont constitués par les coûts, tant en équipement qu'en personnel, nécessaires au fonctionnement de ces systèmes de récupération. 68,71

Après une chirurgie cardiaque, on peut receuillir le sang médiastinal dans le réservoir de cardiotomie utilisé pendant la CEC et le retransfuser au patient. Cette approche est économique et contribue à la diminution du nombre de transfusions, ${ }^{72}$ mais elle devient néfaste quand le chirurgien fait confiance à cette technique au détriment d'une l'hémostase chirurgicale soignée.

Au Canada, la Société Canadienne de la Croix-Rouge ne receuille pas le sang des parents et amis référés par le patient pour son usage propre. Les dons de sang dirigés ne sont utilisés que pour la compatibilité des types sanguins rares ou pour transfuser des plaquettes à un patient réfractaire. ${ }^{7}$ Aux Etats-Unis, plusieurs centres de transfusions ont initié des programmes de donneurs désignés sous la pression de l'opinion publique ou des lois de certains états, mais plusieurs arguments militent contre ce concept; on n'a pas prouvé que le sang de donneur désigné offrait une plus grande sécurité; un fardeau clérical supplémentaire est imposé aux banques de sang; les approvisionnements réguliers de sang peuvent se tarir si les donneurs réguliers cessent d'alimenter les banques pour pallier à des besoins spécifiques. ${ }^{17}$ De plus, les dons dirigés familiaux comportent le risque d'une réaction greffon contre l'hôte si le donneur est homozygote avec un haplotype HLA partagé avec le receveur. ${ }^{73}$ On a aussi rapporté cette complication chez des donneurs non apparentés. $^{74}$

Finalement, pour diminuer l'usage des érythrocytes à la période périopératoire, on pourra éventuellement utiliser les succédanés transporteurs d'oxygène. ${ }^{5}$ Comme ces substituts ne sont pas encore utilisés en clinique, ils ne font pas partie de la présente discussion.

\section{Conclusion}

Malgré les complications associées aux transfusions, les PSH demeurent essentiels et sans eux plusieurs interventions chirurgicales majeures seraient irréalisables. Les cliniciens doivent réaliser que les transfusions de PSH représentent les transplantations de tissus les plus fréquentes entre humains, et que même si on réussissait à éliminer complètement les complications infectieuses, les transfu- sions de PSH ne deviendront jamais complètement inoffensives. De nouvelles complications transfusionnelles comme la réaction du greffon contre l'hôte chez des patients immunocompétents ont fait récemment leur apparition. A l'avenir, d'autres pathogènes, non encore identifiés seront indubitablement transmis par les PHS.

Certaines stratégies peuvent diminuer et quelquefois abolir les besoins de PHS. Malheureusement, quelquesunes ne sont pas disponibles pour nos patients à cause des contraintes du système des soins de santé canadien. Toutefois, les médecins doivent toujours avoir à l'esprit que la première et la principale stratégie permettant d'éviter les PHS consiste en une bonne compréhension des mécanismes physiopathologiques impliqués dans l'anémie et les coagulopathies et leur adhérence inconditionnelle aux critères de la pratique transfusionnelle. .,11-13,17 $^{-17}$

\section{Références}

(Voir page R59) 